\title{
The Physical Fitness Level of Senior High School Male Students in Pesisir Selatan
}

\author{
Dezi Chandra*, Damrah, Arsil \\ Sport Education Program \\ Faculty of Sport Science \\ Padang State University \\ Padang, Indonesia \\ dezicandra@gmail.com
}

\begin{abstract}
The problem in this study is unknown differences in physical fitness male students majoring in Natural Sciences (IPA) and the male student Department of Social Science (IPS). Therefore, this study aims to look at the difference Level Physical Freshness Putra Students majoring in Natural Sciences (IPA) with students Son of Social Sciences (IPS) in Senior High School $1^{\text {st }}$ Linggo Sari Baganti Pesisir Selatan District. This research is a comparative study. The population in this study were male students of class XI Senior High School $1^{\text {st }}$ Linggo Sari Baganti Pesisir Selatan District, consisting of 85 male students. Sampling conducted by the Census, the sample in this study male student IPA numbered 42 people, and IPS students numbered 43 people. Once the data is obtained, then the data analysis techniques in this study using t-test. The results of this study showed that there is differences level of physical fitness between male students from the Natural Science Department and Social Science Department, as evidenced by the $t$ (3.5871) > TTable (1.9870) at $\alpha=0,05$. Jadi male student majoring in Social Science (IPS) better physical fitness level of the male students majoring in Natural Sciences (IPA).
\end{abstract}

Keywords-Physical Freshness

\section{INTRODUCTION}

Education is one of the fields that plays an important role in developing Indonesian people as a whole. The aim of education itself is to develop human resources as early as possible in a directed, comprehensive and optimal manner as well as physically and mentally healthy based on Pancasila. In the field of development and development efforts in all fields through education the government seeks through the administration of subjects contained in the national curriculum that aims to assist in the harmonious and harmonious physical, mental and emotional coaching and development[1].

"National education functions to develop capabilities and shape the nation's character and civilization with dignity in the context of educating the life of the nation, aiming at developing the potential of students to become human beings who believe in and fear God Almighty, have noble, healthy, knowledgeable, capable, creative, independent, and become citizens of a democratic and responsible "[2].

Based on the description above, it can be said that the purpose of education is basically to improve the quality of human resources. Through improving the quality of education, efforts will be made to achieve the formation of a profile of Indonesian people who are intellectually, mentally, physically and spiritually prepared to face a future that increasingly requires science and technology. In the Education Unit Level Curriculum (SBC) it is explained that:

"Physical education in sports and health (Penjasorkes) (2006) is an integral part of education as a whole, aimed at developing aspects of physical fitness, critical thinking skills, social skills, reasoning, emotional stability, moral actions, aspects of healthy lifestyle, and environmental recognition clean through selected physical, sports and health activities that are planned systematically in order to achieve national education goals

Based on the above quotation, it is clear that physical education in sports and health is a part of a comprehensive education in every aspect of achieving national education goals. Physical education sports and health is one part of other subjects that focus more on student activities. Physical education is a means of students doing various physical activities, because in physical education subjects almost all of the material taught is to be achieved, namely: the subject matter and selected material. The main material is material that must be achieved by students in learning while the choice material is the material presented by the choice of the physical education teacher, looking at school facilities and infrastructure and the teacher's readiness in teaching the material.

The existence of the field of physical education and sports education in schools is expected that all school students have good physical fitness. Because physical fitness is a physical condition that describes a person's potential in carrying out his activities well, quickly, and neatly after being able to return to other activities without being tired. Good physical fitness is a valuable possession for every human, especially school students in carrying out activities of daily life. Physical fitness is really needed by students to gain agility, ability, endurance, and high learning ability.

"Physical fitness is something that is influenced by physical activities and sports exercises that are carried out daily. The more physical activity and exercise a person does, the better the level of physical fitness. This is caused by doing physical activity and exercise will increase the body's ability to consume oxygen to the fullest. If the body has been able to increase oxygen 
consumption to the maximum, it will automatically affect the level of physical fitness "[3].

From the above understanding, if all people want to have a good level of physical fitness, there must be a lot of physical activity and sports. Physical activity and sports are very much needed for children who are still taking the path of education in elementary, junior high and high school. Because in the process of education a lot of activities both at school and in the environment. Physical fitness is also very much needed by someone in carrying out activities, if a person's physical fitness level is good then his daily activities will go well this is because the level of physical fitness is good, someone will be able to consume oxygen every day properly. The level of physical fitness will help someone in doing daily work without experiencing significant fatigue.

Then seen from the differences in male students majoring in natural sciences (IPA) with male students majoring in social science (IPS) there are several distinguishing aspects, namely: Teacher aspects, student aspects, aspects of class hours and aspects of sports activities. Aspects of teachers who teach specifically male students majoring in Natural Sciences (IPA) are teachers providing subject matter 1 hour and 2 hours given to students to conduct discussions given by the teacher, while special teachers who teach male students majoring in Social Sciences (IPS) ) gives material 2 hours to students and 1 hour for students to discuss in a material. The aspects of male students majoring in Natural Sciences (IPA) are chosen through the results of an average score of natural science that is higher than the value of social studies, while male students majoring in Social Sciences (IPS) are selected from the results of the average value of social studies higher than Science, The aspect of study hours for male students majoring in Natural Sciences (IPA) their study schedules are from paddy - afternoon, while male students majoring in Social Welfare Studies (IPS) study more in the morning than in the afternoon. Aspects of sports activities for male students majoring in Natural Sciences (IPA) are less likely to do sports activities because more study schedules and science students are more prominent in the field of theory while male students majoring in Social Sciences (IPS) do more sports activities because learning schedules are not too many. Male students majoring in Natural Sciences and male students majoring in Social Sciences have the same teaching and learning activities where the learning hours start from morning to noon. However, each student has other activities outside of school hours such as the majority of Social Sciences major students taking part in PASKIBRA activities which are conducted at the end of school hours, in addition there are other activities that are followed by each male student majoring in Natural Sciences and male students majoring in Social Sciences . Because there is no known difference in the level of physical fitness between male students majoring in Natural Sciences (IPA) with male students majoring in Social Sciences (IPS), the authors through this study are expected to be able to find out how big the difference in physical fitness levels of students of the two classes and which ones the best level of physical fitness, as well as knowing what can affect physical fitness, in order to overcome this physical fitness properly.

\section{RESEARCH METHODOLOGY}

This research belongs to Comparative research. The study was conducted at the same place, namely in SMA Negeri 1 Linggo Sari Baganti, South Pesisir Regency and the study was conducted in May - June 2016. The population in this study were male students of class XI majoring in natural sciences (IPA) with male students of class XI majoring in social science (IPS) at SMA Negeri 1 Linggo Sari Baganti, Pesisir Selatan Regency, which numbered 8 (eight) male classes as many as 85 , so the population in this study amounted to 85 . The technique used in the sample was the Census, which was taken by students Class XI students of natural science (IPA) and Class XI students of social science (IPS) men from both classes with a total sample of 85 male students. The research instruments in this study were 1) 60-meter running, 2) 60-second body lift test, 3) 60-second sitting, 4) Upright jump, 5) 1200-meter run.The data obtained will be analyzed through techniques in accordance with the type and purpose of this study.

The data description and hypothesis testing in this study were processed using descriptive and inferential statistics with the t-test sample bound formula. Before the $t$ test analysis is performed, the analysis requirements test is first performed, namely the normality (Lilliefors Test) data and homogeneity ( $\mathrm{F}$ Test) data, and the $\mathrm{t}$ test can only be used to test the difference in mean of the two samples taken from normal populations and groups homogeneous [4]. After the normality test is done, then the $\mathrm{t}$ test analysis is performed.

\section{RESULT AND DISCUSSION}

1. Physical fitness level of male students of natural science

Based on the results of physical fitness tests for male students majoring in science at SMA Negeri 1 Linggo Sari Baganti, South Pesisir Regency, the highest final score was 17 and the lowest final score was 9, with an average of 12.86 and a standard deviation of 2.10 . From 42 students, it turns out that as many as 6 students $(14.29 \%)$ have physical fitness tests with 9-10 class intervals, then 10 students $(23.81 \%)$ have physical fitness tests with 11-12 class intervals, then as many as 16 students $(38.10 \%)$ had physical fitness tests with 13-14 class intervals, while 8 students $(19.05 \%)$ had physical fitness tests with 15-16 class intervals, and the rest were 2 more samples $(4.76 \%)$ had physical fitness tests with class intervals of 17-18.

2. Physical Freshness Level of Male Students Social Sciences

Based on the results of physical fitness tests for male students majoring in Social Sciences at SMA Negeri 1 Linggo Sari Baganti, South Coastal District, the highest 
final score was 19 and the lowest final score was 11, with an average of 15.16 and a standard deviation of 1.64. Of the 43 students, it turned out that as many as 2 students (4.65\%) had physical fitness tests with 11-12 class intervals, then 12 students $(27.91 \%)$ had physical fitness tests with 13-14 class intervals, then as many as 20 students $(46.51 \%)$ had physical fitness tests with 15-16 class intervals, while 7 students $(16.28 \%)$ had physical fitness tests with 17-18 class intervals, and as many as 2 students $(4.65 \%)$ had physical fitness tests with class intervals of 19-20. Physical fitness is a description of the physical condition of a person's body to perform daily tasks or work without causing significant fatigue. So if you say the relationship between freshness and health will complement each other with each other because physical activity is related to the function of each organ of the body.

Physical fitness are aspects of physical abilities that support students' success in carrying out various activities in daily life without causing significant fatigue. The activity can take the form of day-to-day work and for sudden needs or leisure activities. The higher the physical fitness a person has, the more likely it is to complete a job to enjoy life.

The results of physical fitness tests for male students majoring in natural sciences when compared to the Indonesian physical fitness test table for children aged 16-19 years, it can be determined that of 42 students, as many as 3 students have physical fitness test results in the classification of very poor, 23 students had physical fitness tests results in the less classification and as many as 16 students had physical fitness test results in the moderate classification. Whereas for good and very good classification there is none. The lowest student test results are 9 and the highest student test results are 17. The results of physical fitness tests for male students majoring in social science when compared to the table of Indonesian physical fitness tests for children aged 16-19 years, it can be determined that of the 43 students, none of the students had physical fitness tests in the classification of very poor, as many as 7 students have physical fitness tests results in the classification is less, as many as 33 students have physical fitness test results in the medium classification and 3 students have physical fitness test results in good classification. Whereas there is no good classification. The lowest student test results are 19 and the highest student test results are 11 .

From the above results it is clear that there is a significant comparison between the results of the physical fitness tests for male students majoring in natural sciences (IPA) with male students majoring in social sciences (IPS). The results of physical fitness tests of students majoring in natural sciences with students majoring in social sciences, showed different results, namely only on poor and moderate qualifications. This can be seen from the average between the physical fitness test results of male students of natural sciences and male students of social science who show different results, 12.86 and 15.16 .
Understanding physical fitness is a reflection of the ability of the system functions in the body that can realize an increase in the quality of life in every physical activity. "Physical fitness is a physical ability that can be in the form of aerobic and anaerobic abilities. These physical abilities can be trained through training programs. The work ability of someone who has a high level of freshness is not the same as someone who has a low level of freshness. In people who have a high level of freshness will be able to work for 8 hours with the ability to work $50 \%$ of aerobic capacity, whereas in people with low physical fitness levels are only able to use $25 \%$ of aerobic capacity. Thus it can be said that high physical fitness can support workplace passion [5].Based on the opinion above, it can be defined that physical fitness is very necessary for the body to carry out daily work and is useful for increasing thinking power. To see the results of physical fitness, one of them is the Indonesian Physical Fitness Test. The Indonesian Physical Fitness Test consists of a 60 meter running test, a body lift test for the son for 60 seconds, lying in bed for 60 seconds, a vertical jump and a 1200 meter run for the son.

\section{IV.CONCLUSION}

From the results of the above research, it can be concluded that there are differences in the physical fitness level of male students of the Department of Natural Sciences (IPA) and male students of the Department of Social Sciences (IPS) at SMA Negeri 1 Linggo Sari Baganti, Pesisir Selatan Regency, proven by $\mathrm{t}$ count $(\mathrm{t}$ $3,5871)>\mathrm{t}$ table $(1.9870)$ at $\alpha=0.05$.

\section{REFERENCES}

[1] Undang-Undang Republik Indonesia No. 20 Tahun 2003. Tentang Sistem Pendidikan Nasional. Jakarta: BP Cipta Jaya. 2003, pp. 20.

[2] Depdikbud. "Hasil Seminar Kesegaran Jasmani Nasional". Interval: Depdikbud. 2004, pp. 45.

[3] Efwilza. "Perbedaan Tingkat Kesegaran Jasmani Murid SD No 16 di Kawasan Pertambangan Batu Bara Ombilin Dengan Murid SD no 20 Luar Kawasan Batu Bara Ombilin Kota Sawah Lunto". (Skripsi). Padang. 2002, pp. 37.

[4] Isparjadi. "Statistik Pendidikan". Jakarta: Depdikbud. Dikti: P2LPTK. 1995, pp. 87.

[5] Arsil. "Pembinaan Kondisi Fisik". Padang: Fakultas Ilmu Keolahragaan Universitas Negeri Padang. 1999, pp. 45-46. 